\title{
The Study of Sorption Characteristics of Dried Crab Stick Product Using Dynamic Vapor Sorption
}

\section{Traiphop PHAHOM}

School of Food Technology, Institute of Agricultural Technology, Suranaree University of Technology, Nakhon Ratchasima 30000, Thailand

('Corresponding author's e-mail: traiphop@sut.ac.th)

Received: 16 March 2021, Revised: 20 April 2021, Accepted: 27 April 2021

\begin{abstract}
The research delved into the sorption characteristics of dried crab stick products using dynamic vapor sorption (DVS). The obtained sorption isotherm data, including equilibrium moisture content $(\mathrm{Me})$ and water activity $\left(\mathrm{a}_{\mathrm{w}}\right)$, were fitted with 6 different sorption isotherm models, such as Brunauer-EmmettTeller (BET), Guggenheim-Anderson-Boer (GAB), Pickett-Modified BET, Adam and Shove, BlahovecYanniotis, and Peleg. The results showed that the Peleg model was the best-describing model with a coefficient of determination $\left(R^{2}\right)$, chi-square $\left(\chi^{2}\right)$, root mean square error (RMSE), and standard error of estimate (SEE) ranging from 0.988 to $0.998,0.719$ to $4.349,0.431$ to 2.609 and 0.692 to 1.703 , respectively. According to the classification of the shape of moisture sorption isotherm, the isotherm type III and II were found in this research for adsorption and desorption, respectively. The GAB and BET models were used to estimate monolayer moisture content $\left(\mathrm{M}_{0}\right)$ of the sample and it was found that the $\mathrm{M}_{0}$ ranged from 3.65 to $5.36 \%$ dry basis and 4.57 to $4.83 \%$ dry basis for GAB and BET models, respectively. Blahovec-Yanniotis's model was applied in this work to investigate the contribution of water and the result showed that the contribution of solution water played a major in the moisture changes of the sample during the adsorption and desorption process. Moreover, sorption isotherm data were modeled with 0 and $1^{\text {st }}$ order reaction kinetics, and the results demonstrated that 0 order and $1^{\text {st }}$ order models were the most appropriate model to describe moisture changes behavior of the sample at each relative humidity step for adsorption and desorption, respectively.
\end{abstract}

Keywords: Crab stick, Dynamic vapor sorption, Mathematical modeling, Sorption isotherm, Sorption kinetics

\section{Introduction}

Crab sticks, imitation crabs, or seafood sticks are a type of seafood product that are made from a combination of several steps. Firstly, the fish is headed, gutted, filleted, minced/deboned, washed, and dewatered to obtain the minced fish meat, and the meat is then mixed with cryo-protectants and frozen to obtain frozen surimi. The surimi is mixed with water and other ingredients, shaped and colored prior to cook, pack and freeze to obtain crabstick products. The global surimi production is approximately 820,000 metric tons in 2018 and trends to be 846,5000 metric tons in 2019 (estimated) [1]. Thailand is the largest processor of surimi products and also the largest market in Southeast Asia due to both production and export volume. The total production of finished products is around 130,000 metric tons [1]. The crab stick products contain high moisture content ( $\sim 73 \%$ wet basis) [2]. To preserve the product qualities, frozen storage is selected for extending the product shelf-life. However, frozen storage causes electricity consumption to reduce or remain the temperature under frozen conditions. Therefore, to reduce the cost of frozen storage, drying is an alternative food processing for extending the product shelf-life, and the product obtained from this technique can be stored at room temperature without any changes or minimal 
http://wjst.wu.ac.th

changes in product qualities. For the drying process, the water activity of food products is reduced to a specific level where the product will be safe from microbial growth, chemical reaction, and enzymatic activity causing food deterioration [2].

Moisture sorption isotherm is the relationship between equilibrium moisture content $\left(\mathrm{M}_{\mathrm{e}}\right)$ and equilibrium relative humidity $\left(\mathrm{RH}_{\mathrm{e}}\right)$ or water activity $\left(\mathrm{a}_{\mathrm{w}}\right)$ at a constant temperature and pressure. The isotherm is normally used for designing the dehydration process and evaluating product stability during storage. The sorption isotherm can be performed in 2 ways. The first one is an adsorption isotherm that is obtained by placing a dry sample into different RH levels and measuring the weight gain (when it becomes constant) due to water uptake. Another way is a desorption isotherm that is constructed by placing a wet sample into a different RH level and measuring the weight loss (when it becomes constant) due to dehydration [3]. Several mathematical models such as Brunauer-Emmett-Teller (BET) [4], Guggenheim-Anderson-Boer (GAB) [5], Pickett-Modified BET [6], Peleg [7], Adam and Shove [8] and Blahovec-Yanniotis [9] are often used for describing the moisture sorption behavior of food products. To estimate monolayer moisture content $\left(\mathrm{M}_{0}\right.$; corresponding to $\mathrm{a}_{\mathrm{w}}$ in the monolayer water region of sorption isotherm) which is the moisture content level where food products become less change in their chemical and microbiological properties leading to an increase in the product shelf-life, the GAB and BET models are normally used for $\mathrm{M}_{0}$ prediction in various products including elecampe [10], burdock roots [10], cape gooseberry [11], pears, and apples [12]. The isotherm model from Blahovec and Yanniotis [9] is used the evaluate the contribution of bonded and solution water into the products as presented in the study of Cervenka et al. [10].

Recently, the desorption characteristics of crab sticks by-products using the dehydration technique have been studied by Phahom et al. [2]. However, up to now, there is no information on the sorption characteristics of dried crabstick products. Therefore, this research aimed to study sorption characteristics of the dried crab stick products for both adsorption and desorption isotherms using a dynamic vapor sorption instrument (DVS). The data obtained from the DVS were modeled with 6 different sorption isotherm models to select the best describing model and fitted with reaction order kinetics for evaluating moisture changes behavior at each RH step for both adsorption and desorption processes.

\section{Materials and methods}

\section{Sample preparation}

Crab stick sample was purchased from a superstore in Quetigny, France. The samples were then sliced into $0.5 \mathrm{~cm}$ thickness and dried in a hot air oven at $50{ }^{\circ} \mathrm{C}$ (UF110, Memmert, Germany) for $12 \mathrm{~h}$ to obtain a dried sample with the final moisture content below $5 \%$ wet basis (w.b.). The dried sample was ground to a powder form using a grinder and the powder was then sieved using a wire mesh tray (No.7) to obtain the sample powder with the particle size less than $2,830 \mu \mathrm{m}$.

\section{Moisture sorption isotherm}

A dynamic vapor sorption instrument (DVS- 2000, Surface Measurement Systems, London, U.K.) was used to study the sorption characteristics of a crab stick product. The sample $(30 \pm 1 \mathrm{mg})$ was loaded onto a sample pan which was hung on a wire connected to the microbalance. To equilibrate $\mathrm{a}_{\mathrm{w}}$ of the sample reaching 0.01 before running the adsorption and desorption cycle, the sample was exposed under setting conditions $\left(100 \mathrm{~cm}^{3} / \mathrm{min}\right.$ of a dry nitrogen gas flow rate, $25^{\circ} \mathrm{C}$ and $\left.\mathrm{a}_{\mathrm{w}}=0.01\right)$ for $1,000 \mathrm{~min}$. The relative humidity $(\mathrm{RH})$ of the sample was changed $10 \% \mathrm{RH}$ for each step by increasing from $0-90 \%$ for the adsorption process and then decreasing from $90-0 \%$ for the desorption process. The temperature of DVS was controlled at $25{ }^{\circ} \mathrm{C}$ during the experiment. The rate of moisture changes of $0.002 \%$ dry basis (d.b.)/min for 5 consecutive min or the maximum time reached a pre-set $\%$ RH for 1,500 min was set as a criterion for changing RH to the next step. The sorption data including relative humidity, moisture content, and sorption time were recorded at $5 \mathrm{~min}$ intervals and used in the mathematical modeling section. 


\section{Mathematical modeling}

Six different moisture sorption isotherm models including BET, GAB, Pickett-Modified BET, Peleg, Adam, and Shove and Blahovec-Yanniotis (Eqs. (1) - (6); Table 1) were fitted with sorption isotherm data such as equilibrium moisture content $\left(\mathrm{M}_{\mathrm{e}}\right)$ and water activity $\left(\mathrm{a}_{\mathrm{w}}\right)$ to select the most appropriate model for describing moisture sorption behavior. The moisture changes behavior of the sample at each RH step of both adsorption and desorption processes was determined by fitting the moisture content at each RH step and sorption time with 2 reaction order kinetic models such as 0 and $1^{\text {st }}$ order models (Eqs. (7) - (8); Table 1). The fitting process was performed using the non-linear regression technique by SPSS version 18 for the windows program (SPSS, Inc., Chicago, IL, USA). The most appropriate model was chosen based on the goodness of fit by selecting the model that provided the highest value of the coefficient of determination $\left(\mathrm{R}^{2}\right)$, the lowest values of chi-square $\left(\chi^{2}\right)$, root mean square error (RMSE), and standard error of estimate (SEE) (Eqs. (9) - (11); Table 1).

Table 1 Mathematical modeling.

\begin{tabular}{|c|c|c|c|}
\hline Model name & Model & Equation & References \\
\hline Brunauer-Emmett-Teller; BET & $M_{e}=M_{0} a a_{w} /\left[\left(1-a_{w}\right)\left(1+(a-1) a_{w}\right]\right.$ & (1) & [4] \\
\hline Guggenheim-Anderson-Boer; GAB & $M_{e}=M_{0} a b a_{w} /\left(1-b a_{w}\right)\left(1-b a_{w}+a b a_{w}\right)$ & (2) & [5] \\
\hline Pickett-Modified BET & $M_{e}=a_{w}\left(1-a_{w}^{c}\right) /\left[\left(a+b a_{w}\right)\left(1-a_{w}\right)\right]$ & (3) & [6] \\
\hline Peleg & $M_{e}=a a_{w}^{b}+c a_{w}^{d}$ & (4) & [7] \\
\hline Adam and Shove & $M_{e}=a+b a_{w}+c a_{w}{ }^{2}+d a_{w}{ }^{2}$ & (5) & [8] \\
\hline Blahovec-Yanniotis & $M_{e}=\frac{a_{w}}{a_{1}+b_{1} a_{w}}+\frac{a_{w}}{a_{2}+b_{2} a_{w}}$ & (6) & [9] \\
\hline Zero order reaction & $M=m_{0} \pm k_{0} t$ & (7) & [13] \\
\hline $1^{\text {st }}$ order reaction & $M=m_{0} \exp \left( \pm k_{1} t\right)$ & (8) & [13] \\
\hline Chi-square, $\chi^{2}$ & $\chi^{2}=\sum_{i=1}^{N}\left[\left(Y_{i}-Y_{i}^{\prime}\right)^{2} /(N-n)\right]$ & (9) & \\
\hline Root mean square error, RMSE & $R M S E=\left[\frac{1}{N}\left(\sum_{i=1}^{N}\left(Y_{i}-Y_{i}^{\prime}\right)^{2}\right)\right]^{1 / 2}$ & (10) & \\
\hline Standard error of estimate, SEE & $S E E=\sqrt{\sum_{i=1}^{N}\left(Y_{i}-Y_{i}^{\prime}\right)^{2} / d f}$ & (11) & \\
\hline
\end{tabular}

$\mathrm{a}, \mathrm{a}_{1}, \mathrm{a}_{2}, \mathrm{~b}, \mathrm{~b}_{1}, \mathrm{~b}_{2}$, c, d: parameters of the equation, $\mathrm{a}_{\mathrm{w}}$ : water activity, $\mathrm{k}_{0}$ and $\mathrm{k}_{1}$ : moisture changes rate (\% d.b./min), Mo: monolayer moisture content ( $\%$ d.b. $), \mathrm{m}_{0}$ : moisture content at time $=0$ ( $\%$ d.b. $)$, Me: equilibrium moisture content (\% d.b.), $\mathrm{N}$ : number of data, $\mathrm{n}$ : number of parameter, t: time (min), $\mathrm{Y}_{\mathrm{i}}$ : experimental data, $\mathrm{Y}^{\prime}$ : predicted data.

\section{Results and discussion}

\section{Moisture sorption isotherm}

Sorption isotherm data including sorption time, \% relative humidity, and moisture content for both adsorption, and desorption obtained from dynamic vapor sorption are presented in Figure $\mathbf{1}$ and moisture sorption isotherm of the dried crab stick is exhibited in Figure 2. From the nutrition facts presented on the product packaging, the major components of the crab stick were total carbohydrate $(41.49 \%$ d.b.) and protein $(33.61 \%$ d.b.) which agreed with the study of Phahom et al. [2] who reported that total carbohydrate $(68.08 \%$ d.b.) and protein $(22.96 \%$ d.b. $)$ were the major components of crab stick byproducts. Therefore, it could imply that the shape of sorption isotherms was influenced by both total carbohydrate and protein content present in the sample. According to classification of the types of moisture sorption isotherm by Brunauer et al. [4], the shape of adsorption isotherm followed by type III 
http://wjst.wu.ac.th

isotherm (Floy-Huggins isotherm) which has been used to describe the sorption isotherm shape of pea starch films [14], cowpea and its protein isolate [15], cassava starch and soy protein concentrate based edible films [16]. In addition, the desorption isotherm of the sample followed type II (sigmoid shape or Sshape isotherm) which has been used to describe the sorption isotherm shape of gelatin [17], rice-based instant soup mix [18], and banana flour [19]. The moisture sorption isotherms of the crab stick product (Figure 2) could be divided into 2 main parts following the classification of Phahom et al. [2]. The $1^{\text {st }}$ part covered the $a_{w}$ ranging from 0 - 0.6 that included sorption isotherm region I (strongly bound water) and region II (less strongly bound water and capillary adsorbed water). In this part, rising $\mathrm{a}_{\mathrm{w}}$ from 0 - 0.6 led to increase moisture content from 0 - $7.69 \%$ dry basis (d.b.) (changing by $7.69 \%$ d.b.) and $0-11.54$ $\%$ d.b. (changing by $11.54 \%$ d.b.) for the adsorption and desorption processes (Figure 2), respectively. The $2^{\text {nd }}$ part sorption isotherm covered the $\mathrm{a}_{\mathrm{w}}$ ranging from $0.6-1.0$ which is classified as region III of moisture sorption isotherm (solvent water or free water) of sorption isotherm [20]. It was found that moisture content of the sample increased sharply from $7.69-54.58 \%$ d.b. (changing by $46.89 \%$ d.b.) for adsorption and $11.54-54.58 \%$ d.b. (changing by $43.04 \%$ d.b.) for desorption with increasing $a_{w}$ from $0.6-0.9$. From the results above, it could be implied that a huge moisture change was found in the $2^{\text {nd }}$ part (region III; solvent water or free water). Water in this region behaves like bulk water that has more loosely water interaction compared to other regions therefore, it can serve as a solvent and available for enzymatic activity, chemical reaction, and microbial growth as well as less energy required for water removal leading to easy to remove [2]. However, the limited changes of moisture content were observed in the $1^{\text {st }}$ part because the water in this part is mostly monolayer and multilayer water which is water binding with the biopolymer structure (protein, starch, and fiber) of food or held in the food matrix resulting in difficult to remove $[3,17]$.

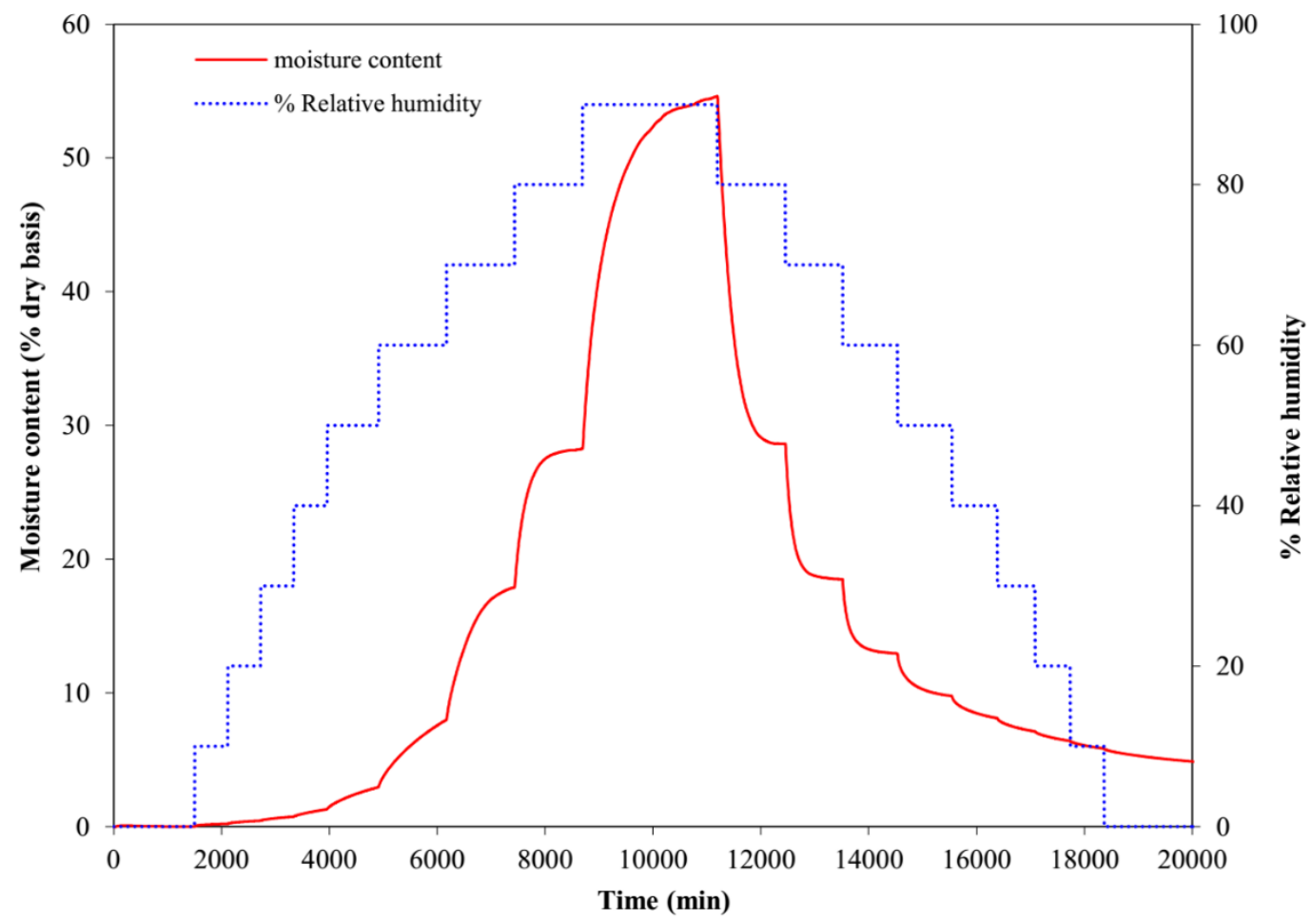

Figure 1 Sorption isotherm data of dried crab stick obtained from dynamic vapor sorption at $25{ }^{\circ} \mathrm{C}$. 


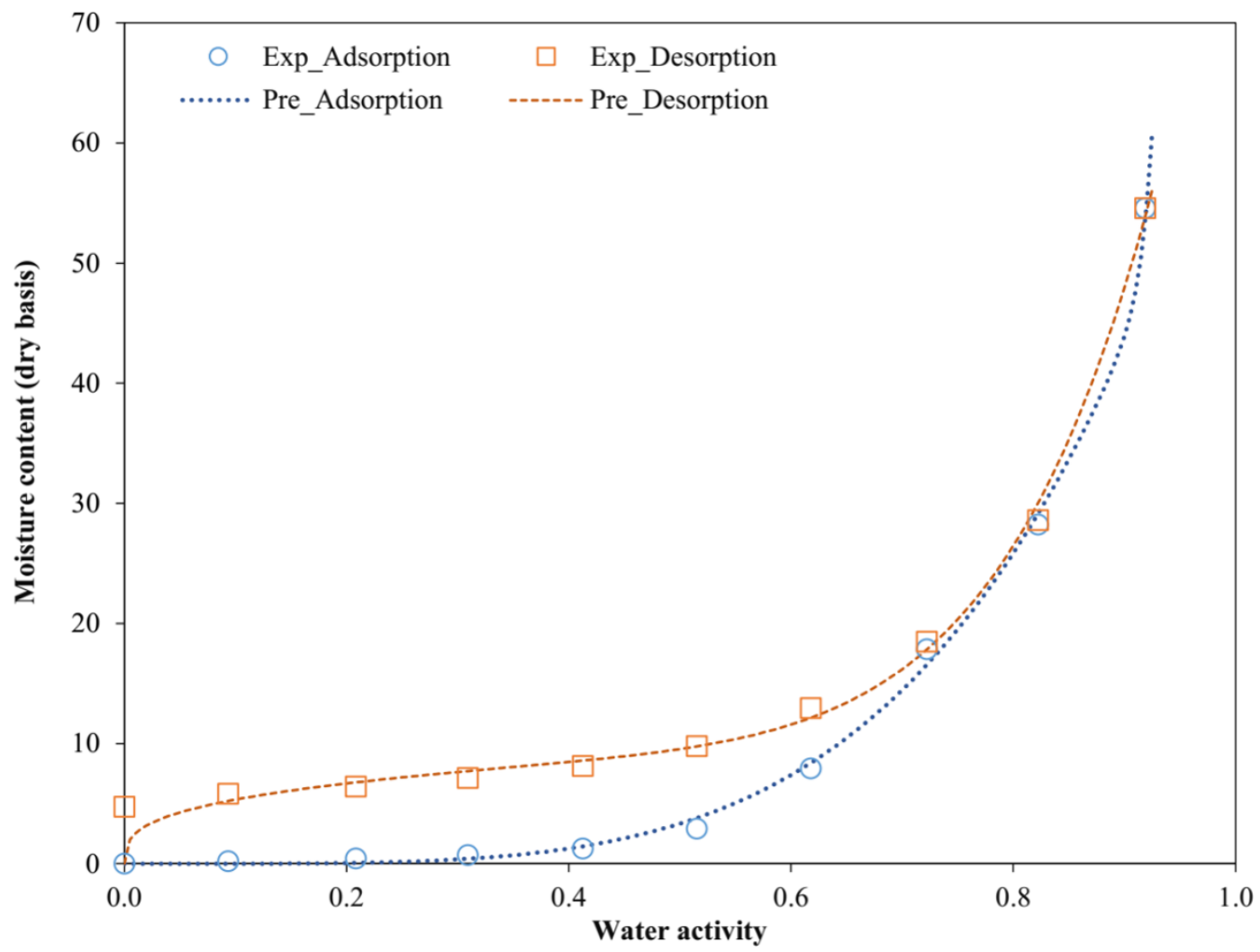

Figure 2 Experimental (Exp) and predicted data (Pre) of sorption isotherms of dried crab stick product using Peleg model.

At the same $\mathrm{a}_{\mathrm{w}}$, the different paths between the moisture content lines of adsorption and desorption are called "hysteresis". The hysteresis is related to the filling and emptying of voids space within the materials, and it reflects the materials structural and conformation rearrangement [3]. Figure 3 shows hysteresis of dried crab stick product and it could be seen that a hysteresis loop extended over the entire range of $\mathrm{a}_{\mathrm{w}}(0-0.9)$ and the shape of hysteresis was well described by the hysteresis of high protein and starchy foods $[17,19,21]$. A huge hysteresis loop was observed at low $a_{w}(<0.6)$ implying that the emptying of voids space in the material was not the same as moisture filling ability (moisture content line of desorption was higher than adsorption line; Figure 2) due to most of the water in this $a_{w}$ range is classified as a monolayer (region I) and multilayer waters (region II). Therefore, the difficulty of moisture removal in this region depends on the capillary shape, the differences in the mobility of the matrix, or the strengthening of interactions between water and biopolymers [17,19]. In contrast, a small hysteresis loop was found at high $\mathrm{a}_{\mathrm{w}}(>0.6)$. It could be explained that when $\mathrm{a}_{\mathrm{w}}$ reached region III (solvent water or free water), water interaction or binding capacity is more loosely compared to the region I and II. Therefore, after the adsorption process, the water in this region is easier to be removed $[17,19]$. 


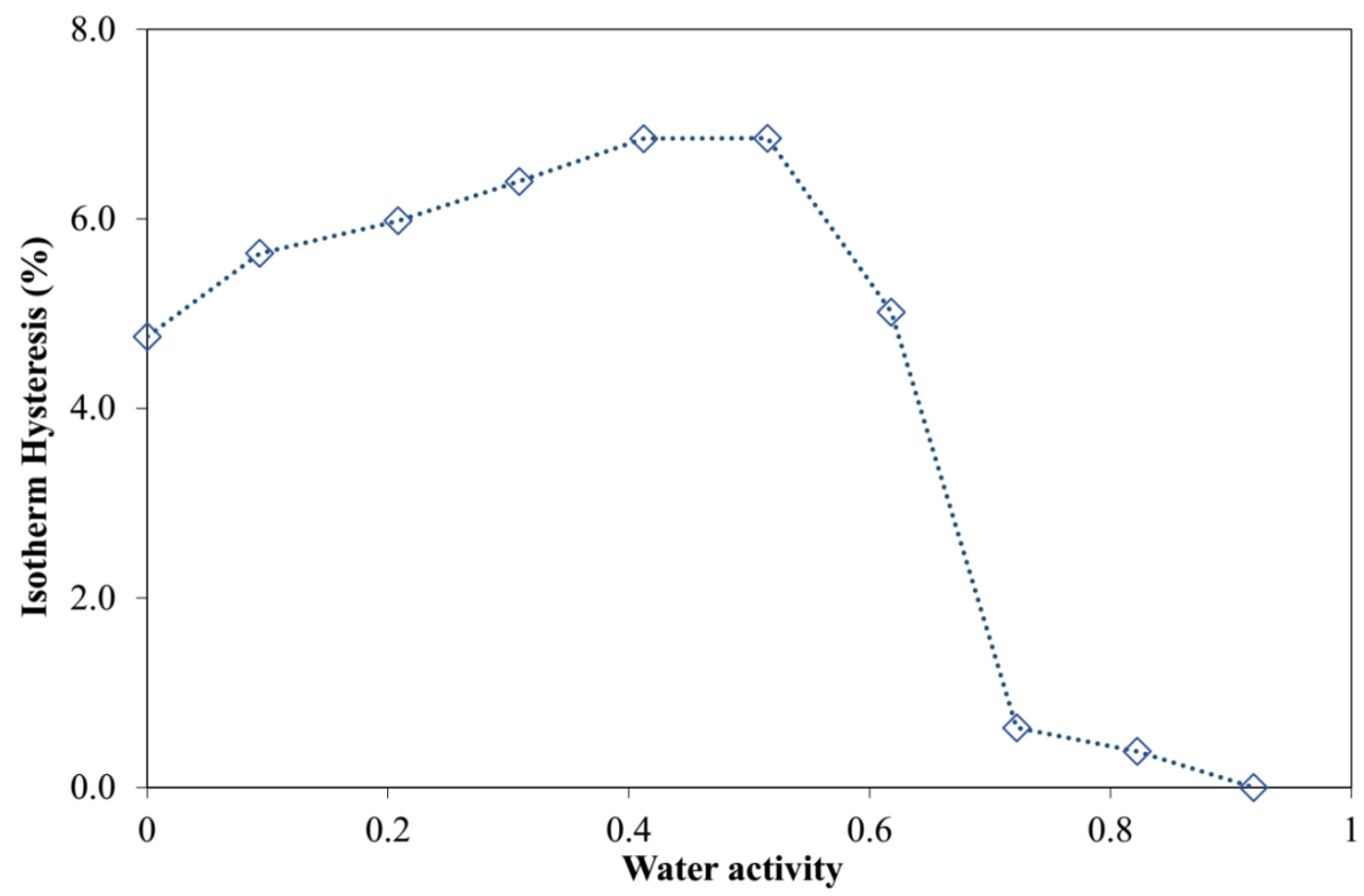

Figure 3 Hysteresis of dried crab stick product.

\section{Mathematical modeling}

To select the most appropriate model for describing the sorption behavior of crab stick product, the sorption data were modeled with 6 different sorption isotherm models (Eqs. (1) - (6); Table 1) and the results of fitting are shown in Table 2. It was found that Peleg's model was the best fit with both adsorption and desorption isotherm data due to the highest $R^{2}(>0.988)$ and the lowest $\chi^{2}(<4.349)$, RMSE $(<2.609)$ and SEE $(<1.703)$. Peleg's model has been successfully used to describe moisture sorption isotherm of several products, for example, gelatin [17], apple [12], and verbena [22]. However, this model is usually used to observe the trend of the isotherm graph (Figure 2) but each obtained parameter has no physical meaning. Therefore, GAB and BET models were applied in this work to better understand the physical meaning of the sorption isotherm parameter, especially monolayer moisture content $\left(\mathrm{M}_{0}\right)$. The $\mathrm{M}_{0}$ is used as an indicator for food product stability because if the moisture content of food is equal to or below $\mathrm{M}_{0}$, the food product will be stable or less change in term quality [12]. As can be seen in Table 2, The estimated $\mathrm{M}_{0}$ of the crab stick product was 3.65 and $4.57 \%$ d.b. for GAB and BET model, respectively. In addition, Blahovec-Yanniotis's model (Eq. (6); Table 1) was used to study the contribution of bonded and solution water in the sample. The model consisted of 2 important terms: The $1^{\text {st }}$ term $\left(a_{w} / a_{1}+b_{1} a_{w}\right)$ and $2^{\text {nd }}$ term $\left(a_{w} / a_{2}+b_{2} a_{w}\right)$ refer to the contribution of bonded water and solution water, respectively. The fitting result using this model is presented in Table 2 and the estimation of bonded water and solution water of the sample at different $\mathrm{a}_{\mathrm{w}}$ levels are presented in Figure 4. It could be seen that the contribution of solution water was greater than bonded water for both adsorption and desorption and the solution water trendily increased with increasing $\mathrm{a}_{\mathrm{w}}$ implying that at high $\mathrm{a}_{\mathrm{w}}$, solution water plays a major role for moisture changing due to a region III (solvent or free water) of moisture sorption isotherm. Moreover, a small change of moisture content of bound water could be observed in the adsorption process but fewer changes in moisture content of bound water was found desorption process. It may be due to a huge influence of moisture changes comes from solution water as presented in Figure 4. 
http://wjst.wu.ac.th

A similar observation was found in the study of Cervenka et al. [10]. Rockland [23] stated that unbound water in food materials became clearer at high moisture content.

Table 2 The fitting results of moisture sorption isotherm data with different isotherm models.

\begin{tabular}{|c|c|c|c|c|c|c|}
\hline \multirow[b]{2}{*}{ Sorption type } & \multirow[b]{2}{*}{ Model } & \multicolumn{4}{|c|}{ Statistical parameters } & \multirow[b]{2}{*}{ Model constants } \\
\hline & & $R^{2}$ & $\begin{array}{c}\chi^{2} \\
\text { (\% d.b. })\end{array}$ & $\begin{array}{c}\text { RMSE } \\
\text { (\% d.b.) }\end{array}$ & $\begin{array}{c}\text { SEE } \\
(\% \text { d.b. })\end{array}$ & \\
\hline \multirow[t]{6}{*}{ Adsorption } & Adam and Shove & 0.946 & 25.938 & 15.563 & 4.158 & $\mathrm{a}=4.292, \mathrm{~b}=-61.176, \mathrm{c}=278.623, \mathrm{~d}=-160.983$ \\
\hline & Peleg & 0.998 & 0.719 & 0.431 & 0.692 & $\mathrm{a}=3.36 \mathrm{E}+04, \mathrm{~b}=101.521, \mathrm{c}=68.299, \mathrm{~d}=4.354$ \\
\hline & Pickett-Modified BET & 0.995 & 2.223 & 1.556 & 1.315 & $\mathrm{a}=0.357, \mathrm{~b}=-0.289, \mathrm{c}=6.770$ \\
\hline & Blahovec-Yanniotis & 0.984 & 7.871 & 4.722 & 2.291 & $a_{1}=3.38 E+06, b_{1}=1.71 E+06, a_{2}=0.155, b_{2}=0.151$ \\
\hline & BET & 0.974 & 9.174 & 7.339 & 2.856 & $\mathrm{M}_{\mathrm{o}}=4.827, \mathrm{a}=1.417$ \\
\hline & GAB & 0.942 & 23.607 & 16.525 & 4.285 & $\mathrm{M}_{\mathrm{o}}=3.648, \mathrm{a}=-2.06 \mathrm{E}+08, \mathrm{~b}=1.016$ \\
\hline \multirow[t]{6}{*}{ Desorption } & Adam and Shove & 0.909 & 32.672 & 19.603 & 4.667 & $a=9.053, b=-49.157, c=268.546, d=-171.060$ \\
\hline & Peleg & 0.988 & 4.349 & 2.609 & 1.703 & $a=11.253, b=0.324, c=78.663 ; d=7.140$ \\
\hline & Pickett-Modified BET & 0.988 & 3.769 & 2.638 & 1.712 & $\mathrm{a}=-0.163, \mathrm{~b}=0.160, \mathrm{c}=-0.898$ \\
\hline & Blahovec-Yanniotis & 0.969 & 11.241 & 6.744 & 2.737 & $\mathrm{a}_{1}=-3.41 \mathrm{E}-04, \mathrm{~b}_{1}=3.70 \mathrm{E}+04, \mathrm{a}_{2}=0.080, \mathrm{~b}_{2}=0.061$ \\
\hline & BET & 0.978 & 5.834 & 4.668 & 2.277 & $\mathrm{M}_{\mathrm{o}}=4.570, \mathrm{a}=6.58 \mathrm{E}+07$ \\
\hline & GAB & 0.988 & 3.852 & 2.697 & 1.731 & $\mathrm{M}_{\mathrm{o}}=5.360, \mathrm{a}=102.497, \mathrm{~b}=0.981$ \\
\hline
\end{tabular}

$\mathrm{a}, \mathrm{a}_{1}, \mathrm{a}_{2}, \mathrm{~b}, \mathrm{~b}_{1}, \mathrm{~b}_{2}$, c and $\mathrm{d}$ are model parameters, $\mathrm{M}_{\mathrm{o}}$ is monolayer moisture content (\% d.b.) 


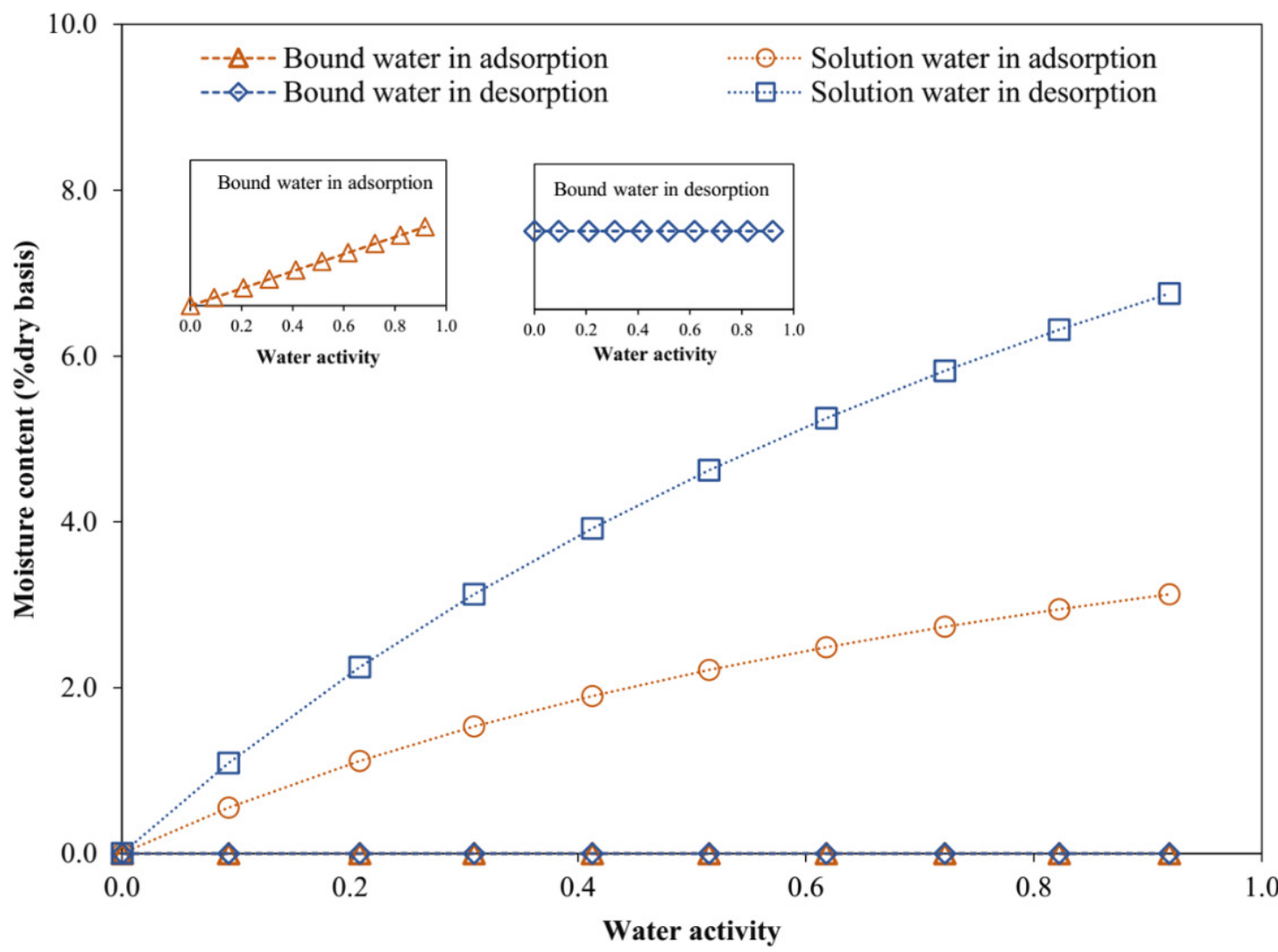

Figure 4 Bound (its zoom-in version presented in the small figures) and solution water of adsorption and desorption predicted from Blahovec-Yanniotis model.

The reaction order kinetics were used to study the moisture changing behavior at each RH step of adsorption and desorption isotherms. The obtained sorption data such as moisture content and sorption time were fitted with two reaction order kinetics namely, 0 and $1^{\text {st }}$ order models. The 0 -order model (simple linear) is normally used for describing a linear trend of the relationship between food quality and time while an exponential trend of the quality changes during storage can be described by the $1^{\text {st }}$ order model. The results of fitting are illustrated in Table 3. The 0-order model was the most appropriate model for describing adsorption data with $R^{2}, \chi^{2}$, RMSE and SEE ranging from $0.677-0.989,1.04 \mathrm{E}-04$ 9.33E00, 1.03E-04 - 9.30E00, and 1.02E-02 - 3.05E00, respectively, implying that the moisture changes behavior of the sample in adsorption process could be described by a linear trend with the rate of moisture change $\left(\mathrm{k}_{0}\right)$ ranging from 2.35E-04 - 7.32E-03\% d.b./min. Moreover, increasing RH led to an increase in $\mathrm{k}_{0}$ because at beginning of the adsorption process (low RH level), the increment of water is influenced by moisture absorption on the sample surfaces but at the later process (high RH level), the moisture changes are influenced by the combination between moisture absorption on the sample surfaces and moisture diffusion leading to increase $\mathrm{k}_{0}$. In contrast, the $1^{\text {st }}$ order model was better fit with desorption data compared to 0 order model with $R^{2}, \chi^{2}$, RMSE and SEE ranging from $0.594-0.983,3.83 \mathrm{E}-04-9.41 \mathrm{E} 00$, $3.77 \mathrm{E}-04-9.34 \mathrm{E} 00$ and $1.95 \mathrm{E}-02-3.06 \mathrm{E} 00$, respectively and the rate of moisture change $\left(\mathrm{k}_{1}\right)$ ranging from 9.40E-05 - 5.28E-04 \% d.b./min. Decreasing RH led to a decrease in $\mathrm{k}_{1}$ implying that at beginning of the desorption process (high RH level), most of the water in this RH range is in the region III (solvent or free water) of sorption isotherm. The water interaction or binding capacity is loose or weak so, water removal can be performed easily but at low RH level, water removal becomes harder due to the water in 
http://wjst.wu.ac.th

this RH level is in the region I (strongly bound water) or II (less strong bound water) that is the water interacts or binds with food biopolymers or the water is held or absorbed in the solid matrix of food that is difficult to remove resulting in lower $\mathrm{k}_{1}$. A similar trend was found in the study of Phahom et al. [2] and Doymaz [24] who reported that the moisture changes during the dehydration process could be described by the exponential model (Approximation of diffusion and Midilli et al. models) with $R^{2}>0.998$.

Table 3 The fitting results of sorption isotherm data with reaction order kinetics of crab stick product.

\begin{tabular}{|c|c|c|c|c|c|c|c|c|}
\hline Sorption type & Model & RH step & $R^{2}$ & $\begin{array}{c}\chi^{2} \\
\text { (\% d.b.) }\end{array}$ & $\begin{array}{c}\text { RMSE } \\
\text { (\% d.b.) }\end{array}$ & $\begin{array}{c}\text { SEE } \\
\text { (\% d.b.) } \\
\end{array}$ & $\begin{array}{c}m_{0} \\
(\% \text { d.b. }) \\
\end{array}$ & $\begin{array}{c}k_{0} \text { or } k_{1} \\
(\% \text { d.b. } / \mathrm{min}) \\
\end{array}$ \\
\hline \multirow[t]{18}{*}{ Adsorption } & \multirow[t]{9}{*}{ Zero order } & $0-10$ & 0.888 & $2.27 \mathrm{E}-04$ & 2.24E-04 & $1.50 \mathrm{E}-02$ & 0.08 & $2.35 \mathrm{E}-04$ \\
\hline & & $10-20$ & 0.969 & $1.04 \mathrm{E}-04$ & 1.03E-04 & 1.02E-02 & 0.26 & 3.19E-04 \\
\hline & & $20-30$ & 0.976 & 1.44E-04 & 1.42E-04 & $1.20 \mathrm{E}-02$ & 0.50 & 4.27E-04 \\
\hline & & $30-40$ & 0.989 & 2.37E-04 & 2.33E-04 & $1.53 \mathrm{E}-02$ & 0.82 & $8.21 E-04$ \\
\hline & & $40-50$ & 0.982 & $3.44 \mathrm{E}-03$ & $3.41 \mathrm{E}-03$ & $5.85 \mathrm{E}-02$ & 1.55 & $1.58 \mathrm{E}-03$ \\
\hline & & $50-60$ & 0.981 & $3.51 \mathrm{E}-02$ & 3.48E-02 & 1.87E-01 & 3.72 & $3.67 \mathrm{E}-03$ \\
\hline & & $60-70$ & 0.892 & 7.79E-01 & 7.73E-01 & 8.81E-01 & 10.73 & $6.95 E-03$ \\
\hline & & $70-80$ & 0.677 & $1.81 \mathrm{E}+00$ & $1.80 \mathrm{E}+00$ & $1.34 \mathrm{E}+00$ & 23.18 & $5.34 \mathrm{E}-03$ \\
\hline & & $80-90$ & 0.750 & $9.33 \mathrm{E}+00$ & $9.30 \mathrm{E}+00$ & $3.05 E+00$ & 40.33 & 7.32E-03 \\
\hline & \multirow[t]{9}{*}{$1^{\text {st }}$ order } & $0-10$ & 0.823 & $3.59 \mathrm{E}-04$ & $3.53 \mathrm{E}-04$ & $1.89 \mathrm{E}-02$ & 0.10 & $1.42 \mathrm{E}-03$ \\
\hline & & $10-20$ & 0.944 & $1.86 \mathrm{E}-04$ & $1.83 \mathrm{E}-04$ & $1.36 \mathrm{E}-02$ & 0.28 & $8.60 \mathrm{E}-04$ \\
\hline & & $20-30$ & 0.958 & 2.49E-04 & $2.45 \mathrm{E}-04$ & $1.57 \mathrm{E}-02$ & 0.51 & $6.65 \mathrm{E}-04$ \\
\hline & & $30-40$ & 0.974 & $5.74 \mathrm{E}-04$ & $5.64 \mathrm{E}-04$ & 2.39E-02 & 0.84 & $7.53 \mathrm{E}-04$ \\
\hline & & $40-50$ & 0.955 & $8.75 \mathrm{E}-03$ & $8.65 \mathrm{E}-03$ & $9.33 \mathrm{E}-02$ & 1.65 & $6.67 \mathrm{E}-04$ \\
\hline & & $50-60$ & 0.947 & $9.71 \mathrm{E}-02$ & $9.63 \mathrm{E}-02$ & $3.11 \mathrm{E}-01$ & 4.08 & $5.88 \mathrm{E}-04$ \\
\hline & & $60-70$ & 0.845 & $1.12 \mathrm{E}+00$ & $1.11 \mathrm{E}+00$ & $1.06 \mathrm{E}+00$ & 11.35 & 4.36E-04 \\
\hline & & $70-80$ & 0.650 & $1.97 \mathrm{E}+00$ & $1.95 \mathrm{E}+00$ & $1.40 \mathrm{E}+00$ & 23.45 & $1.93 \mathrm{E}-04$ \\
\hline & & $80-90$ & 0.713 & $1.07 \mathrm{E}+01$ & $1.07 \mathrm{E}+01$ & $3.27 \mathrm{E}+00$ & 41.30 & $1.41 \mathrm{E}-04$ \\
\hline \multirow[t]{18}{*}{ Desorption } & \multirow[t]{9}{*}{ Zero order } & $90-80$ & 0.736 & $1.26 \mathrm{E}+01$ & $1.25 \mathrm{E}+01$ & $3.55 \mathrm{E}+00$ & 43.90 & $1.63 \mathrm{E}-02$ \\
\hline & & $80-70$ & 0.560 & $2.27 \mathrm{E}+00$ & $2.25 \mathrm{E}+00$ & $1.50 \mathrm{E}+00$ & 22.75 & $5.51 \mathrm{E}-03$ \\
\hline & & $70-60$ & 0.618 & 4.85E-01 & $4.81 \mathrm{E}-01$ & $6.95 \mathrm{E}-01$ & 15.24 & $3.01 \mathrm{E}-03$ \\
\hline & & $60-50$ & 0.814 & $9.22 \mathrm{E}-02$ & $9.13 \mathrm{E}-02$ & $3.03 \mathrm{E}-01$ & 11.55 & $2.17 \mathrm{E}-03$ \\
\hline & & $50-40$ & 0.925 & $1.22 \mathrm{E}-02$ & $1.21 \mathrm{E}-02$ & $1.10 \mathrm{E}-01$ & 9.29 & $1.60 \mathrm{E}-03$ \\
\hline & & $40-30$ & 0.955 & $2.91 \mathrm{E}-03$ & $2.86 \mathrm{E}-03$ & $5.37 \mathrm{E}-02$ & 7.89 & $1.22 \mathrm{E}-03$ \\
\hline & & $30-20$ & 0.974 & 8.97E-04 & 8.84E-04 & $2.98 \mathrm{E}-02$ & 6.99 & $9.76 \mathrm{E}-04$ \\
\hline & & $20-10$ & 0.981 & 4.45E-04 & $4.38 \mathrm{E}-04$ & $2.10 \mathrm{E}-02$ & 6.31 & $8.22 \mathrm{E}-04$ \\
\hline & & $10-0$ & 0.976 & $1.96 \mathrm{E}-03$ & $1.95 \mathrm{E}-03$ & $4.42 \mathrm{E}-02$ & 5.64 & $4.82 \mathrm{E}-04$ \\
\hline & \multirow[t]{9}{*}{$1^{\text {st }}$ order } & $90-80$ & 0.803 & $9.41 \mathrm{E}+00$ & $9.34 \mathrm{E}+00$ & $3.06 \mathrm{E}+00$ & 46.00 & $5.28 E-04$ \\
\hline & & $80-70$ & 0.594 & $2.10 \mathrm{E}+00$ & $2.08 \mathrm{E}+00$ & $1.45 \mathrm{E}+00$ & 23.08 & $2.94 E-04$ \\
\hline & & $70-60$ & 0.642 & $4.55 \mathrm{E}-01$ & $4.51 \mathrm{E}-01$ & $6.73 E-01$ & 15.36 & $2.28 \mathrm{E}-04$ \\
\hline & & $60-50$ & 0.832 & 8.30E-02 & 8.22E-02 & $2.87 \mathrm{E}-01$ & 11.62 & 2.12E-04 \\
\hline & & $50-40$ & 0.935 & 1.07E-02 & $1.06 \mathrm{E}-02$ & 1.03E-01 & 9.31 & $1.87 \mathrm{E}-04$ \\
\hline & & $40-30$ & 0.961 & $2.55 \mathrm{E}-03$ & $2.52 \mathrm{E}-03$ & 5.04E-02 & 7.90 & $1.64 E-04$ \\
\hline & & $30-20$ & 0.978 & $7.77 E-04$ & $7.65 \mathrm{E}-04$ & $2.78 \mathrm{E}-02$ & 6.99 & $1.47 \mathrm{E}-04$ \\
\hline & & $20-10$ & 0.983 & 3.83E-04 & $3.77 E-04$ & $1.95 \mathrm{E}-02$ & 6.32 & $1.36 \mathrm{E}-04$ \\
\hline & & $10-0$ & 0.982 & $1.43 \mathrm{E}-03$ & $1.43 E-03$ & $3.78 \mathrm{E}-02$ & 5.66 & $9.40 \mathrm{E}-05$ \\
\hline
\end{tabular}

$\mathrm{m}_{0}, \mathrm{k}_{0}$ and $\mathrm{k}_{1}$ are initial moisture content (\% d.b.), rate of moisture change (\% d.b./ min) for 0 and $1^{\text {st }}$ order kinetic equation, respectively. 
http://wjst.wu.ac.th

\section{Conclusions}

The sorption characteristics of the dried crab stick product were studied using a dynamic vapor sorption instrument. Six moisture sorption isotherm models were modeled with the sorption isotherm data and Peleg's model was the best fit with the data. The shapes of moisture sorption isotherm were classified as Type III and II for adsorption and desorption, respectively. The monolayer moisture content obtained from GAB and BET models were ranging from 3.65 to $5.36 \%$ d.b. and 4.57 to $4.83 \%$ d.b., respectively. For the moisture sorption kinetics, 0 and $1^{\text {st }}$ order reaction model were well fit with moisture changes data for adsorption and desorption processes, respectively. Therefore, the obtained desorption and adsorption model could be applying for designing the drying process and optimum point of storage of crab stick product in the further experiment.

\section{Acknowledgement}

This research was supported by the junior research fellowships program (French Embassy in Bangkok) in cooperation between Agrosup Dijon and Suranaree University of Technology, Thailand.

\section{References}

[1] Surimi Market update, Available at: https://surimitech123.com/wp-content/uploads/2019/10/1hSurimi-Market-Update-September-2019-Surimi-Forum-Madrid-September-2019.pdf, accessed February 2021.

[2] T Phahom, N Juntharat, P Premsuttarat, Y Paosunthia and G Roudaut. Evaluation of desorption isotherms, drying characteristics and rehydration properties of crab stick by-product. Heat Mass Transf. 2021; 57, 1039-52.

[3] AH Al-Muhtaseb, WAM McMinn and TRA Magee. Moisture sorption isotherm characteristics of food products: A review. Trans. Ins. Chem. Eng. 2002; 80, 118-28.

[4] S Brunauer, PH Emmett and E Teller. Adsorption of gases in multi-molecular layers. J. Am. Chem. Soc. $1938 ; \mathbf{6 0}, 309-19$.

[5] C Van den Berg and S Bruin. Water activity and its estimation in food systems. In: LB Rockland and GF Stewart (Eds.). Water activity: Influences on food quality. Academic, New York, 1981, p. 147-77.

[6] G Pickett. Modification of the Brunauer-Emmett-Teller theory of multi-molecular adsorption. $J$. Am. Chem. Soc. 1945; 67, 1958-62.

[7] M Peleg. Assessment of a semi-empirical four parameter general model for sigmoid moisture sorption isotherms. J. Food Process. Eng. 1993; 16, 21-37.

[8] J Chirife and HA Iglesias. Equations for fitting water sorption isotherms of foods: Part 1-A review. J. Food Technol. 1978; 13, 159-74.

[9] J Blahovec and S Yanniotis. Modified classification of sorption isotherms. J. Food Eng. 2009; 91, $72-7$.

[10] L Cervenka, J Kubinova, L Juszczak and M Witczak. Moisture sorption isotherms and glass transition temperature of elecampe (Inula helenium L.) and burdock (Arctium lappa L.) root at 25 ${ }^{\circ}$ C. Food Sci. Technol. Int. 2012; 18, 81-91.

[11] A Vega-Galvez, J Lopez, K Ah-Hen, MJ Torres and R Lemus-Mondaca. Thermodynamic properties, sorption isotherms and glass transition temperature of cape gooseberry (Physalis peruviana L.). Food Technol. Biotechnol. 2014; 52, 83-92.

[12] ND Mrad, C Bonazzi, N Boudhrioua, N Kechaou and F Courtois. Moisture sorption isotherms, thermodynamic properties, and glass transition of pears and apples. Dry. Technol. 2012; 30, 1397406.

[13] CMD Man and A Jones. Shelf-life evaluation of foods. Aspen Publishers, Maryland, 2000, p. 1-24.

[14] B Saberi, QV Voung, S Chockchaisawasdee, JB Golding, CJ Scarlett and CE Stathopoulos. Water sorption isotherm of pea starch edible films and prediction models. Foods 2006; $5,1$. 
http://wjst.wu.ac.th

[15] E Ayranci and O Duman. Moisture sorption isotherms of cowpea (Vigna unguiculata L. Walp) and its protein isolate at 10, 20 and $30{ }^{\circ} \mathrm{C}$. J. Food Eng. 2005; 70, 83-91.

[16] CE Chinma, CC Ariahu and J Alakali. Moisture sorption and thermodynamic properties of cassava starch and soy protein concentrate based edible films. Int. J. Food Sci. Technol. 2013; 48, 2400-7.

[17] G Aguirre-Alvarez, T Foster and SE Hill. Modelling of isotherms and their hysteresis analysis in gelatin from different sources. CyTA J. Food. 2013; 11, 68-74.

[18] Y Singh and K Prasad. Sorption isotherms modeling approach of rice-based instant soup mix stored under controlled temperature and humidity. Cogent Food Agric. 2015; 1, 1-11.

[19] P Khawas and SC Deka.Moisture sorption isotherm of underutilized culinary banana flour and its antioxidant stability during storage. J. Food Process. Pres. 2017; 41, 1-10.

[20] DR Heldman and DB Lund. Handbook of Food Engineering. Marcel Dekker, New York, 1992, p.653-687

[21] JG Kapsalis. Influences of hysteresis and temperature on moisture sorption isotherms. In: LB Rockland and LR Beuchat (Eds.). Water activity: Theory and applications to food. Marcel Dekker, New York, 1987, p.173-213.

[22] M Kouhila, A Belghit, M Daguenet and BC Boutaleb. Experimental determination of sorption isotherms of mint (Mentha viridis), sage (Salvia officinalis) and verbena (Lippia citriodora). J. Food Eng. 2001; 47, 281-7.

[23] LB Rockland.The practical approach to better low moisture foods: Water activity and storage stability. Food Technol. 1996; 23, 1241-9.

[24] I Doymaz. Mathematical modeling of drying of tomato slices using infrared radiation. J. Food Process. Pres. 2014; 38, 389-96. 